\section{Efficacy of Cork Granulates as a Top Coat Substrate Component for Seed Germination as Compared to Vermiculite}

\author{
Arianna Bozzolo ${ }^{1,3}$ and Michael R. Evans ${ }^{2}$
}

ADDITIONAL INDEX WORDS. air-filled pore, water-holding capacity, germination, impatiens, vinca, geranium, tomato, pepper

SUMMARY. A top coat is a lightweight substrate component used in seed germination. The seeds are typically placed on a substrate such as peat and then the seeds are covered with a layer of the top coating substrate. The top coat serves to maintain adequate moisture around the seeds and to exclude light. Vermiculite and cork granulates $(1 \mathrm{~mm})$ were used as top coat substrates for seed germination to determine if cork granulates could be successfully used as an alternative to vermiculite. The cork granulates had a bulk density of $0.16 \mathrm{~g} \cdot \mathrm{cm}^{-3}$, which was higher than that of vermiculite that had a bulk density of $0.12 \mathrm{~g} \cdot \mathrm{cm}^{-3}$. Cork granulates had an air-filled pore space of $22.7 \%(\mathrm{v} / \mathrm{v})$, which was higher than vermiculite which was $13.2 \%$. The water-holding capacity of vermiculite was $63.4 \%$ $(\mathrm{v} / \mathrm{v})$, which was higher than that of cork granulates that was $35.1 \%$. Seeds of 'Rutgers Select' tomato (Solanum lycopersicum), 'Dazzler Lilac Splash' impatiens (Impatiens walleriana), 'Orbital Cardinal Red' geranium (Pelargonium $\times$ bortorum), 'Better Belle' pepper (Capsicum annumm), and 'Cooler Grape' vinca (Catharanthus roseus) were placed on top of peat and covered with a $4-\mathrm{mm}$ top coating of either vermiculite or cork granulates. For tomato, impatiens, and vinca, days to germination were similar between seeds germinated using vermiculite and granulated cork as a top coat. Days to germination of geranium and pepper were significantly different with geranium and pepper seeds coated with cork granulates germinating 0.7 and 1.5 days earlier than those coated with vermiculite. For tomato, impatiens, and geranium, the number of seeds germinating per plug tray was similar between the top coats. Number of seeds germinating per tray for pepper and vinca were significantly different. Pepper had an average of 2.8 more seeds germinating per tray, and vinca had an average of 2.4 more seeds germinating per tray if seeds were germinated using granulated cork vs. vermiculite. For all species, dry shoot and dry root weights were similar for seedlings germinated using cork and vermiculite top coats.

$\mathrm{V}$ ermiculite is a naturally occurring sheet silicate mineral, formed by hydrothermal alteration of minerals such as biotite and phlogopite (Brindley and Brown, 1980). Flakes of unprocessed vermiculite are mica-like and contain interlayer water within their structure. When the flakes are heated rapidly, above $870{ }^{\circ} \mathrm{C}$, the water flashes into steam and the flakes expand into accordion-like particles. This process is called exfoliation, and the resulting material is lightweight, fire resistant with excellent insulating and absorption properties (Potter, 2000). Vermiculite has been widely used as a horticulture substrate component

${ }^{1}$ Researcher, Department of Horticulture, 311 Plant Science Building, University of Arkansas, Fayetteville, AR 72701

${ }^{2}$ Professor, Department of Horticulture, 318 Plant Science Building, University of Arkansas, Fayetteville, AR 72701

${ }^{3}$ Corresponding author. E-mail: abozzolo@uark.edu. upon germination (Dana and Lerner, 2001). Walker et al. (1984) reported that watering was less frequent when a top coating was used in seed germination. A vermiculite top coat was also shown to prevent surface packing of the substrate, reduce the incidence of tipping over of seedlings, and increase the seedling rating as compared with no top coating (Walker, 1984).

Cork oak (Quercus suber), native to southwestern Europe and northwestern Africa, is a forest tree species grown in the Mediterranean basin countries, where it is exploited for cork production (Manzanera et al., 1993). Cork is produced by the cork cambium in the outer bark of the cork oak, and it is considered a natural and renewable raw product (Silva et al., 2005). Cork consists essentially of suberin, lignin, and cellulose (Kolattukudy, 1978) and also contains a small amount of fatty acids, terpenes, long chain aliphatic compounds, and saccharides (Pereira, 1988). These compounds give cork unique properties such as high elasticity and low permeability to liquids. Because of these physical properties, cork has a wide range of traditional applications, such as in green buildings and handicrafts, but cork stoppers for wine bottles remains the primary use and the highest value market (Silva et al., 2005). Waste cork from the corkbased products industry, low-quality cork, and virgin cork (rough and irregular cork bark coming from the cork tree the first time it is harvested) are all used to produce cork granulates (Gil, 2009). This granulated cork material, discarded and unsuitable for cork products production, can be used in a variety of applications and different task such as in industrial components, various fillers, insulators, or as compounds to be mixed with other materials.

Limited research has been reported regarding granulated cork in substrates. Bazzocchi and Giorgioni (1987) reported that nephthytis (Syngonium

\begin{tabular}{llll}
\hline $\begin{array}{l}\text { Units } \\
\begin{array}{l}\text { To convert U.S. to SI, } \\
\text { multiply by }\end{array}\end{array}$ & U.S. unit & SI unit & $\begin{array}{l}\text { To convert SI to U.S., } \\
\text { multiply by }\end{array}$ \\
\hline 29.5735 & $\mathrm{fl} \mathrm{oz}$ & $\mathrm{mL}$ & 0.0338 \\
2.54 & inch $(\mathrm{es})$ & $\mathrm{cm}$ & 0.3937 \\
25.4 & inch $(\mathrm{es})$ & $\mathrm{mm}$ & 0.0394 \\
28,350 & $\mathrm{oz}$ & $\mathrm{mg}$ & $3.5274 \times 10^{-5}$ \\
1.7300 & $\mathrm{oz} / \mathrm{inch}^{3}$ & $\mathrm{~g} \cdot \mathrm{cm}^{-3}$ & 0.5780 \\
1 & $\mathrm{ppm}$ & $\mathrm{mg} \cdot \mathrm{L}^{-1}$ & 1 \\
$\left({ }^{\circ} \mathrm{F}-32\right) \div 1.8$ & ${ }^{\circ} \mathrm{F}$ & ${ }^{\circ} \mathrm{C}$ & $\left({ }^{\circ} \mathrm{C} \times 1.8\right)+32$
\end{tabular}


podophyllum) grown in cork oak bark had slower growth than when grown in a peat-based substrate. In this case, the lower growth rate was attributed to nutritional and water deficiencies. Aguado et al. (1993) reported that geranium plants grown in substrates with cork had lower dry shoot weights than plants grown in peat-based substrates without cork. The reduced growth rate was attributed to a possible phytotoxic effect of phenolic compounds in the cork. However, other researchers have reported that cork oak bark was a suitable substrate for growing plants. Carmona et al. (2011) reported that particle density, bulk density, effective porosity, container capacity, and aeration capacity of cork was within the requirements for nursery substrates as recommended by Carmona and Abad (2008). Additionally, Ortega et al. (1996) reported a study in which they examined the growth of different species in a phytotoxicity bioassay of cork bark substrates and found that radicle growth of chinese cabbage (Brassica pekinensis), lettuce (Lactuca sativa), pepper (Capsicum annuum), and radish (Raphanus sativus) plants was higher in waterwashed cork than in vermiculite. The authors speculated that the hot water wash technique used to wash the cork before use removed phytotoxic compounds.

Despite the benefits reported for using vermiculite as a top coating in seed germination, the relatively high costs of vermiculite as a result of mining, transportation, and heating, reported environmental and health concerns (Bandli and Gunter, 2006), and the desire to use byproducts in substrates have resulted in an interest in alternatives to vermiculite in horticulture substrates. The objective of this research was to compare the efficacy of vermiculite and granulated cork as a top coating for seed germination and seedling production.

\section{Materials and methods}

Physical PROPERTIES OF VERMICULITE AND CORK GRANULATES. Vermiculite (1-mm diameter) was obtained from Sun Gro Horticulture (Bellevue, WA). Cork granulates ( $1-\mathrm{mm}$ diameter) were obtained from Amorim Cork Composites (Chicago, IL). Vermiculite and cork were packed into $345-\mathrm{mL}$ porometers $(7.5 \times 7.5 \mathrm{~cm})$, and bulk density (grams per cubic centimeter), total pore space (percent $\mathrm{v} / \mathrm{v}$ ), air-filled pore space (percent $\mathrm{v} / \mathrm{v}$ ), and water-holding capacity (percent $\mathrm{v} / \mathrm{v}$ ) were determined using procedures described by Bilderback and Fonteno (1993) and Evans and Gachukia (2007). Five replications of each material were conducted. Significant differences in physical properties between cork and vermiculite were determined using a $t$-test.

Germination AND SEEDLING GROWTH USING VERMICULITE AND CORK GRANULATES AS TOP COATS. Sphagnum peat (Sun Gro Horticulture) was amended with calcitic limestone to adjust the $\mathrm{pH}$ of the sphagnum peat (peat) to 5.8 . Five-cell-by-fivecell mini-plug trays (round 273 with a volume of $5 \mathrm{~mL}$ per cell) were filled with the amended peat up to $4 \mathrm{~mm}$ from the rim of the plug cells. Seeds of 'Rutgers Select' tomato, 'Dazzler Lilac Splash' impatiens, 'Orbital Cardinal Red' geranium, 'Better Belle' pepper, and 'Cooler Grape' vinca were sown onto the surface of the peat, and the seeds were covered with a $4-\mathrm{mm}$ top coating of either vermiculite or cork granulates. The mini-plug trays were placed on expanded metal benches in a polycarbonate-glazed greenhouse. Temperature set points were $65^{\circ} \mathrm{F}$ for heating and $75{ }^{\circ} \mathrm{F}$ for cooling. Light levels during the trial period averaged 350 to $450 \mu \mathrm{mol} \cdot \mathrm{m}^{-2} \cdot \mathrm{s}^{-1}$ at $1200 \mathrm{HR}$. Initially, the seeds were misted four to five times per day with clear water to maintain a moist top coat. After they developed two true leaves, plants were irrigated as required to maintain a moist substrate with a nutrient solution containing $25 \mathrm{ppm}$ nitrogen using $15 \mathrm{~N}-2.2 \mathrm{P}-12.5 \mathrm{~K}$ fertilizer (Excel 15-5-15 Cal Mag; Everris International, Geldermalsen, The Netherlands).

Days to germination were recorded for each plug cell, and the average days to germinate and the number of seeds germinating per plug tray was recorded. After 5 weeks, the seedlings were harvested and the roots were washed. Shoots and roots were placed in a drying oven at $70{ }^{\circ} \mathrm{C}$, and after drying, the dry shoot and dry root weights per plug tray were measured. The dry shoot and dry root weights of each tray were divided by the number of plants germinated in the tray to obtain the average seedling dry shoot and dry root weight.
A five-cell-by-five-cell mini-plug tray served as an experimental unit. The experimental design was a complete randomized block with six blocks and each species and top coating appearing once per block. The experiment was repeated three times.

For each species, the $t$-test was conducted to determine if significant differences in days to germination, number of seeds germinating per tray, average dry shoot weight, and average dry root weight occurred between seeds germinated with a cork granulate or vermiculite top coat.

\section{Results and discussion}

PHYSICAL PROPERTIES OF VERM I C U L I T E A N D CORK GRANULATES. The bulk density of cork granulates was $0.16 \mathrm{~g} \cdot \mathrm{cm}^{-3}$ and was higher than vermiculite that had a bulk density $0.12 \mathrm{~g} \cdot \mathrm{cm}^{-3}$. Cork granulates had a total pore space of $57.8 \%(\mathrm{v} / \mathrm{v})$ and a water-holding capacity of $35.1 \%$, which were significantly lower than those of vermiculite at $76.5 \%$ and $63.4 \%$, respectively (Fig. 1). However, the air-filled pore space of cork granulates was $22.7 \%$ and was higher than that of vermiculite which was $13.2 \%$ (Fig. 1).

The physical properties of substrates have been reported to be largely determined by the size of the particles of the substrate components (Buck and Evans, 2010). Larger particles tend to result in the creation of larger pores (macropores) in substrates. Larger pores tend to drain after irrigation and provide the air-filled pore space of the substrate (Bunt, 1983; Raviv and Leith, 2008). Conversely, Tilt et al. (1987) found that increasing the number of fine particles in a substrate increased the number of smaller pores (micropores) and increased water-holding capacity of the substrate. In this experiment, vermiculite and cork granulates had similar particle sizes but different physical proprieties. When vermiculite is thermally treated, the macroscopic plate layers were spread apart in an accordion-like structure. The space between the layers reduced the particle density of the vermiculite, which in turn resulted in a lower bulk density than the granulated cork. Additionally, water was absorbed inbetween the layers of the vermiculite. This allowed vermiculite to hold water not only in the micropores but 
also in the particle layers, and this gave vermiculite a higher waterholding capacity than the granulated cork that held water only in the micropores created by the particles. Additionally, although the vermiculite and granulated cork were both an average $1 \mathrm{~mm}$ across in size, the cork had more of an angular structure than the vermiculite. This would have resulted in the two materials packing in the porometers differently. Angular materials tend to pack less densely and create more macropores. This would explain why although particle sizes were the same, the granulated cork had a higher air-filled pore space.
Germination AND SEedling GROWTH USING VERMICULITE AND CORK GRANULATES AS TOP COATS. TOmato seeds germinated after $8.1 \mathrm{~d}$ when top coated with vermiculite, which was not different from the 8.3 d required for tomato seeds coated with cork granulates to germinate (Table 1). An average of 23.4 tomato seeds germinated per tray when top coated with vermiculite, and this value was not different for seeds germinated with cork granulates, which had an average of 22.8 seeds germinated per tray. Tomato seedlings had similar dry shoot weights of 49.1 and $48.5 \mathrm{mg}$ when germinated with vermiculite or cork granulate top coat, respectively.

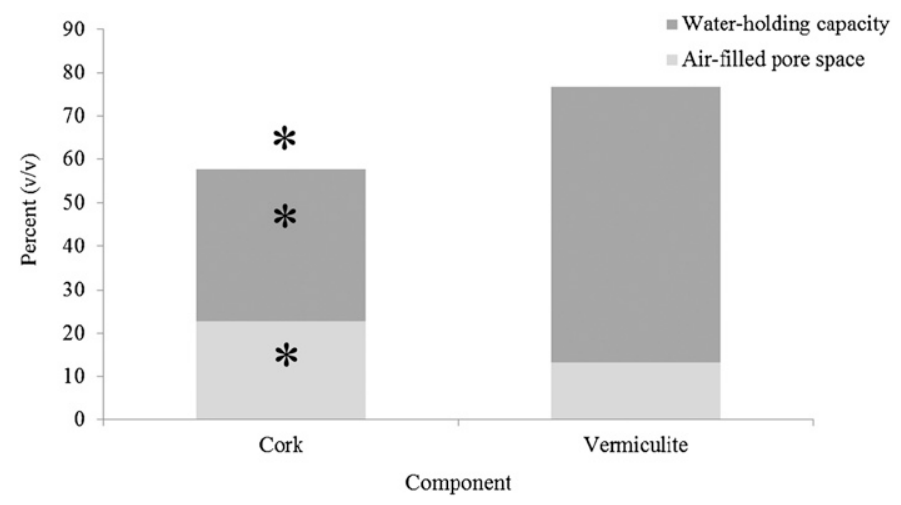

Fig. 1. Total pore space, water-holding capacity, and air-filled pore space (percent $\mathrm{v} / \mathrm{v})$ of $1-\mathrm{mm}(0.04 \mathrm{inch})$ granulated cork and $1-\mathrm{mm}$ vermiculite. The combined value of water-holding capacity and air-filled pore space was the total pore space. *Values for cork granulate were significantly different from that of vermiculite at $P>F$ of $0.05 ; 1 \mathrm{~g} \cdot \mathrm{cm}^{-3}=0.5780 \mathrm{oz} /$ inch $^{3}$.

Table 1. Time to germination, number of seeds germinated per tray, average seedling dry root weights, and average seedling dry shoot weights of tomato, impatiens, geranium, pepper, and vinca germinated and grown with a top coating of either vermiculite or granulated cork. ${ }^{2}$

\begin{tabular}{|c|c|c|c|c|c|}
\hline Species & Top coat ${ }^{y}$ & $\begin{array}{c}\text { Time to } \\
\text { germination }(\mathrm{d})\end{array}$ & $\begin{array}{c}\text { Seeds germinated } \\
\text { (no./tray) }\end{array}$ & $\begin{array}{l}\text { Shoot dry } \\
\text { wt }(\mathrm{mg})^{\mathrm{x}}\end{array}$ & $\begin{array}{l}\text { Root dry } \\
\text { wt }(\mathrm{mg})^{x}\end{array}$ \\
\hline \multirow[t]{2}{*}{ Tomato } & Vermiculite & 8.1 & 23.4 & 49.1 & 20.7 \\
\hline & Cork & $8.3 \mathrm{NS}$ & $22.8 \mathrm{NS}$ & $48.5 \mathrm{NS}$ & $20.5 \mathrm{NS}$ \\
\hline \multirow[t]{2}{*}{ Impatiens } & Vermiculite & 9.6 & 24.1 & 27.4 & 11.7 \\
\hline & Cork & $9.6 \mathrm{NS}$ & $24.4 \mathrm{NS}$ & $28.4 \mathrm{NS}$ & $11.5 \mathrm{NS}$ \\
\hline \multirow[t]{2}{*}{ Geranium } & Vermiculite & 5.4 & 22.7 & 83.9 & 23.8 \\
\hline & Cork & $4.7^{*}$ & $24.5 \mathrm{NS}$ & $60.6 \mathrm{NS}$ & $14.9 \mathrm{NS}$ \\
\hline \multirow[t]{2}{*}{ Pepper } & Vermiculite & 14.1 & 19.7 & 25.9 & 9.6 \\
\hline & Cork & $12.6^{*}$ & $22.5^{*}$ & $26.2 \mathrm{NS}$ & $10.1 \mathrm{NS}$ \\
\hline \multirow[t]{2}{*}{ Vinca } & Vermiculite & 12.4 & 19.3 & 16.6 & 7.0 \\
\hline & Cork & $11.8 \mathrm{NS}$ & $21.7^{*}$ & $15.9 \mathrm{NS}$ & $6.2 \mathrm{Ns}$ \\
\hline
\end{tabular}

${ }^{z}$ Seeds were sown in five-cell-by-five-cell mini-plug trays [ round 273 with a volume of $5 \mathrm{~mL}(0.17 \mathrm{fl} \mathrm{oz})$ per cell] onto the surface of amended peat and covered with $4 \mathrm{~mm}$ of respective top coating; $1 \mathrm{~mm}=0.04$ inch.

"Vermiculite was l-mm "fine" vermiculite, and cork was l-mm cork granulate.

${ }^{x}$ The dry shoot and dry root weights of each tray were divided by the number of plants germinated in the tray to obtain the average seedling dry shoot and dry root weight; $1 \mathrm{mg}=3.5274 \times 10^{-5} \mathrm{oz}$.

Ns, ${ }^{*}$ Nonsignificant or significantly different from vermiculite within species at $P>F$ of 0.05 , respectively.
Tomato dry root weights were 20.7 and $20.5 \mathrm{mg}$ when germinated using a vermiculite and cork granulates top coat, respectively, and were not different between the two top coats.

Impatiens seeds germinated after $9.6 \mathrm{~d}$ when top coated with either vermiculite or cork granulates (Table 1 ). An average of 24.1 impatiens seeds germinated per tray when top coated with vermiculite, and this value was not different for seeds germinated with cork granulates, which had an average of 24.4 seeds germinated per tray. Impatiens seedlings had similar dry shoot weights of 27.4 and $28.4 \mathrm{mg}$ when germinated with vermiculite or cork granulate top coat, respectively. Impatiens dry root weights were 11.7 and $11.5 \mathrm{mg}$ when germinated using a vermiculite and cork granulate top coat, respectively, and were not different between the two top coats.

Geranium seeds germinated after $5.4 \mathrm{~d}$ when top coated with vermiculite, which was significantly longer than the $4.7 \mathrm{~d}$ required for geranium top coated with cork granulate (Table 1 ). An average of 22.7 geranium seeds germinated per tray when top coated with vermiculite, and this value was not different for seeds germinated with cork granulate, which had an average of 24.5 seeds germinated per tray. Geranium seedlings had similar dry shoot weights of 83.9 and $60.6 \mathrm{mg}$ when germinated with vermiculite or cork granulate top coat, respectively. Geranium dry root weights were 23.8 and $14.9 \mathrm{mg}$ when germinated using a vermiculite and cork granulate top coat, respectively, and were not different between the two top coats.

Pepper seeds germinated after $14.1 \mathrm{~d}$ when top coated with vermiculite, which was significantly longer than the $12.6 \mathrm{~d}$ required for impatiens top coated with cork granulate to germinate (Table 1). An average of 19.7 pepper seeds germinated per tray when top coated with vermiculite, and this value was significantly lower than for seeds germinated with cork granulate, which had an average of 22.5 seeds germinated per tray. Pepper seedlings had similar dry shoot weights of 25.9 and $26.2 \mathrm{mg}$ when germinated with vermiculite or cork granulate top coat, respectively. Pepper dry root weights were 9.6 and $10.1 \mathrm{mg}$ when germinated using a vermiculite and cork granulate top coat, respectively, and were not different between the two top coats. 
Vinca seeds germinated after $12.4 \mathrm{~d}$ when top coated with vermiculite, which was not different from the $11.8 \mathrm{~d}$ required for impatiens top coated with cork granulates to germinate (Table 1). An average of 19.3 vinca seeds germinated per tray when top coated with vermiculite, and this value was lower than for seeds germinated with cork granulate, which had an average of 21.7 seeds germinated per tray. Vinca seedlings had similar dry shoot weights of 16.6 and $15.9 \mathrm{mg}$ when germinated with vermiculite or cork granulated top coat, respectively. Vinca dry root weights were 7.0 and $6.2 \mathrm{mg}$ when germinated using a vermiculite and cork granulate top coat, respectively, and were not different between the two top coats.

Although Bazzocchi and Giorgioni (1987) reported reduced growth of nephthytis grown in cork oak bark, they attributed reduced plant growth in cork to nutritional and water deficiencies as a result of the physical properties of the cork substrate. Although Aguado et al. (1993) reported reduced growth of geranium grown in a cork oak-based substrate, they proposed that reduced growth was because of phytotoxic phenolic compounds in the cork. We observed no reduced germination and no reduced seedling growth for species germinated with a top coating of granulated cork as compared with vermiculite. The results in our experiment may have been different because only a small amount of cork was used and the cork was applied only to the surface of the substrate as a top coat and not incorporated into the peat. By only using a small amount of granulated cork and only using it as a top coat, the developing seedling rooted into the peat substrate below the top coat and, therefore, may not have experienced phytotoxic levels of phenolic compounds and would have had adequate moisture retained by the peat to not have experienced water stress.

Interestingly, we observed reduced days to germination and/or increased germination numbers for several species tested when a cork granulate top coating was used as compared with vermiculite. This may have occurred as a result in the changes in physical properties that occurred in the vermiculite top coat over time. Vermiculite has been reported to collapse over time as a result of irrigation
(Dole and Gibson, 2006). The layers of the vermiculite particles collapse and the water-holding capacity and air-filled pore space decreases. This is in contrast to the granulated cork which was rigid and suberized and had no apparent changes over the experimental period. Therefore, the cork top coat provided adequate moisture and air space but also maintained a more constant environment during germination and seedling growth. The more constant germination environment provided by the cork top coat may have resulted in a reduction in days to germination and a higher germination number for some of the species tested. Interestingly, the two species that displayed increased germination numbers were pepper and vinca. This would be expected if the collapse of the vermiculite over time were resulted in reduced germination numbers since the longer germination time provided a longer time period for the vermiculite particles to collapse and negatively affect seed germination.

\section{Conclusion}

No deleterious effects related to days to germination, number of seeds germinating, seedling dry shoot weight, or seedling dry root weight were observed for species tested in this study using cork granulate as a top coating as compared with using vermiculite as a top coating. Therefore, although cork granulate had held less water and had a higher air-filled pore space than vermiculite of a similar particle size, its physical properties were appropriate to allow it to be used as a top coat substrate for seed germination and plug production. In some species, decreased days to germination and increased number of seeds germinating were observed when cork granulate was used as the top coating. This may have occurred as a result of vermiculite particles collapsing over time and a concomitant reduction in the vermiculite's ability to hold water and provide for air-filled pore space around the seed. Therefore, cork granulates were successfully used as an alternative to fine vermiculite as a top coating for seed germination and plug production.

\section{Literature cited}

Aguado, M.T., M.C. Ortega, M.T. Moreno, and M.P. Suarez. 1993. Growth and nutrient content of pelargonium grown in cork oak bark substrate. Acta Hort. 342:293296.

Bandli, B.R. and M.E. Gunter. 2006. A review of scientific literature examining the mining history, geology, mineralogy, and amphibole asbestos health effects of the Rainy Creek igneous complex, Libby, Montana USA. Inhal. Toxicol. 18:949-962.

Bazzocchi, R.P.D. and M.E. Giorgioni. 1987. Effetti del paclobutrazolo e di alcuni substrati su Syngonium podophyllum. Colture Protette 5:45-50.

Bilderback, T.E. and W.C. Fonteno. 1993. Impact of hydrogel on physical properties of coarse-structured horticultural substrates. J. Amer. Soc. Hort. Sci. 118:217-222.

Boodley, J.W. and R.J. Sheldrake. 1977. Cornell peat-lite mixes for commercial plant growing. Cornell Info. Bul. 43.

Brindley, G.W. and G. Brown. 1980. Crystal structure of clay minerals and their X-ray identification, p. 495. 3rd ed. Mineralogical Soc. Monogr. 5. Mineralogical Society, London, UK.

Buck, J.S. and M.R. Evans. 2010. Physical properties of ground parboiled fresh rice hulls used as a horticultural root substrate. HortScience 45:643-649.

Bunt, A.C. 1983. Physical properties of mixtures of peats and minerals of different particle size and bulk density for potting substrates. Acta Hort. 150:143-153.

Carmona, E. and M. Abad. 2008. Aplicacion del compost en viveros y semilleros, p. 399-342. In: J. Moreno and R. Moral (eds.). Compostaje. Mundi-Prensa, Madrid, Spain.

Carmona, E., M.T. Moreno, P. Pajuelo, M.D. Martínez, and J. Ordovás. 2011. Use of composted cork as a nursery substrate for lettuce. Acta Hort. 923:305-309.

Dana, M.N. and R.B. Lerner. 2001. Starting seeds indoors, p. 37-42. In: General horticulture. Dept. Hort. Purdue Univ. Coop. Ext. Serv. HO-14-W, West Lafayette, IN

Dole, J.M. and J.L. Gibson. 2006. Cutting propagation: A guide to propagating and producing floriculture crops. lst ed. Ball Publishing, Batavia, IL.

Evans, M.R. and M.M. Gachukia. 2007. Physical properties of sphagnum peatbased root substrates amended with perlite or parboiled fresh rice hulls. HortTechnology 17:312-315.

Gil, L. 2009. Cork composites: A review. Materials 2:776-789.

Kolattukudy, P.E. 1978. Chemistry and biochemistry of the aliphatic components 


\section{Research Reports}

of suberin, p. 43-84. In: G. Kahl (ed.). Biochemistry of wounded plant tissues. Walter de Gruyter, Berlin, Germany.

Manzanera, J.A., R. Astorga, and M.A. Bueno. 1993. Somatic embryo induction and germination in Quercus suber L. Silvae Genetica 42:90-93.

Nelson, P.V. 1998. Greenhouse operation and management. 5th ed. Prentice Hall, Upper Saddle River, NJ.

Ortega, C., M.T. Moreno, J. Ordovás, and M.T. Aguado. 1996. Behavior of different horticultural species in phytotoxicity bioassays of bark substrates. Sci. Hort. 66:125-132.

Pereira, H. 1988. Chemical composition and variability of cork from Quercus suber L. Wood Sci. Technol. 22:211-218.
Potter, M.J. 2000. Vermiculite, p. 83.183.4. In: U.S. Geological Survey minerals yearbook 2000. 14 Dec. 2012. <http:// minerals.usgs.gov/minerals/pubs/ commodity/vermiculite/index.html>.

Raviv, M. and J.H. Leith. 2008. Soilless culture: Theory and practice. Elsevier Publishing, San Diego, CA.

Silva, S., M. Sabino, E. Fernandes, V. Correlo, L. Boesel, and R. Reis. 2005. Cork: Properties, capabilities and applications. Intl. Mater. Rev. 50:345-365.

Stamps, R.H. and M.R. Evans. 1999. Growth of Dracaena marginata and Spathiphyllum 'Petite' in sphagnum peat- and coir dust-based growing media. J. Environ. Hort. 17:49-52.
Tilt, K.M., T.E. Bilderback, and W.C. Fonteno. 1987. Particle size and container size effects growth of three ornamental species. J. Amer. Soc. Hort. Sci. 112:981-984.

Walker, E.K. 1984. Flue-cured tobacco seedlings: Effects of seedling age, transplanting time, and seeding density on seedling growth and crop production factors. The Lighter 54:16-21.

Walker, E.K., L.B. Reynolds, and W.D. Rogers. 1984. Influences of seed size, vermiculite cover, and watering regime on germination, survival, and growth of flue-cured tobacco seedlings under glass. The Lighter 54:22-30. 